\title{
THE EXECUTIVE OFFICE AND FISCAL AND ECONOMIC POLICY
}

\author{
Gerhard Colm*
}

A question about the economic and fiscal functions in the Executive Office of the President would not have been raised fifty years ago. There were, of course, the economic and fiscal problems with which the President has been concerned all through history. There were problems of farm settlement, tariff policy, of monetary policy, of management of the debt, and of national public works. Each of these problems was handled in one particular department of the Government, and the President discussed the issues, presumably with the head of that particular department. If he wanted to hear the views of others, the problem at hand might have been brought before a cabinet meeting or, in some cases, the President might have discussed the matter with trusted friends. There was, however, no thought that the President would be given a statutory responsibility in these fields besides his general supervisory and legislative responsibilities. Nor was there any thought that the President needed a special staff in his own office besides the staff of the various departments and agencies.

During the Great Depression, matters of economic and fiscal policy became of paramount importance for the President. President Roosevelt tackled these problems with the help of personal advisers-his so-called brain trust. He often used as personal advisers not the cabinet officers, but some trusted men placed below the head of a department or agency. In addition, a number of ad hoc emergency councils were created. But no systematic attempt was made to provide continuing staff services for the President in the economic and fiscal field prior to the Reorganization Act of r939.

\section{The Budget and Accounting Act of ig2I}

The first major debate concerning staff services for the President in the field of economic and fiscal policy centered around the President's role in budget preparation and budget execution. ${ }^{1}$ Until the adoption of the Budget and Accounting Act in $x 92 x_{1}{ }^{1}$ the Treasury Department simply compiled the various departmental budget requirements and passed them on to Congress. There was no executive budget policy and therefore no fiscal function for the President to perform. The Budget and Accounting Act made transmission of the budget a presidential duty. Thereby, the

* Dr. Rer. Pol. r92I, Freiburg University. Economist, Council of Economic Advisers, Executive Office of the President, x946-52; Chief Economist, National Planning Council, since 1952. Author, Essars IN Public Finance and Fiscal Policy (1955).

${ }^{1} 42$ STAT. 20, 3I U. S. C. \$\$ I-I6 (1952). For details about the budget process, sec Artuur Smithes, The Budgetary Process in the United States (1955); and Jesse Burkhead, Government Budgeting (1956). 
President became responsible for making specific recommendations for appropriations and, under certain conditions, for changes in taxation, borrowing, or debt redemption. The promoters of this legislation fully realized its significance in the development of the institution of the Presidency in the United States. Through the responsibility for preparing an executive budget, the President would be given an instrument which could help him in discharging more effectively his supervisory and coordinating responsibility. Budget making was conceived not merely as a financial function; it was envisaged as a means for determining the use of various governmental activities in line with their relative importance; it was intended to provide a method for supervising the effectiveness of departmental organization and performance. It was to be a tool for implementing policy decisions. The enthusiasts expected that the responsibility for budget policy would make presidential leadership more real.

The Taft Commission, which began the consideration of a budget system before the First World War, recommended a presidential budget chiefly in the interest of improving governmental procedures. At the time of enactment, after the end of the First World War, drastic reduction in federal spending had become a primary objective of the Government, and presidential leadership in this effort was sought. It was hoped that the executive budget would serve this purpose. Nevertheless, some proponents of the legislation advocated that the staff work should be performed by the Treasury Department in order to avoid an overlapping of functions between the Treasury and an independent Budget Bureau. Our own precedents and the British experience both warned of such a danger. But others recommended the establishment of a Bureau of the Budget directly responsible to the President. The advocates of an independent Bureau were fearful lest the Treasury should come to exercise a decisive power over all other departments. Further, they argued that the President could discharge his coordinating function only if he had at his disposal a staff agency serving him directly and that a super-department like the British Treasury was not suitable for the American system of government. This conflict in viewpoint resulted in a compromise. The Director of the Budget was to be appointed by the President and charged with assisting the President in his budget making function. But the Bureau was "to be created in the Treasury Department." This was an arrangement which fairly invited the Secretary of the Treasury to regard the Budget Bureau as one of the offices under his jurisdiction. On the other hand, it permitted the Director of the Budget to interpret his role as serving directly under the President. This ambiguity created much confusion and embarrassment.

\section{The Reorganization Act of 1939}

The issue came to a head through the work of the President's Committee on Administrative Management in 1937. This Committee had a task force on fiscal management of which A. E. Buck was chairman. This task force recommended that the Budget Bureau be made an integral part of the Treasury Department. 
The Committee itself (whose members were Louis Brownlow, Charles E. Merriam, and Luther Gulick) reversed this recommendation. They favored the establishment of an Executive Office of the President in which the Bureau of the Bugdet, along with a few other staff agencies, would be located. Under the Reorganization Act of $x 939$, these recommendations became law.

In the Executive Office were placed also the National Resources Planning Board and other agencies. In the field of public-works planning, both from the aspect of supporting long-range economic growth and economic stabilization, the Budget Bureau and the NRPB were given joint responsibilities by executive order. With respect to the budget, the Treasury maintained a primary responsibility for advising the President on the revenue side of the budget. Even after the establishment of the Budget Bureau in the Executive Office, the Treasury continued to claim a primary responsibility in advising the President on all matters of financial policy. This situation resulted repeatedly in conflicts which the President had to resolve. Secretaries of the Treasury made repeated attempts to reopen the issue of the position of the Budget Bureau. ${ }^{2}$ Contrary to the practice of several other department heads, the Secretary of the Treasury has, as far as I know, never, in person, attended a hearing of the Budget Bureau in connection with appropriations for the Treasury Department. There is an attitude which may be called an "institutional" objection to the philosophy expressed by the Reorganization Act of 1939. Friction between Treasury and Budget Bureau appears to have been sharpest during the years following the Reorganization Act of 1939, when the Budget Bureau expanded rapidly not only in staff, but also in its scope of responsibility and influence with the President. In recent years, during which the Budget Bureau has been markedly less aggressive, there has been less occasion for friction and an improvement in working relations is reported.

By the creation in the Executive Office of agencies concerned with fiscal and economic matters, the President was given a more direct responsibility in these fields than he would have had if the staff work had been lodged within the cabinet departments. In this latter case, the President would still have the duty of transmitting recommendations to Congress, but, in the absence of a staff in his own office, he would have to rely much more on the advice of his cabinet members.

What then were the reasons which motivated the advocates of the Executive Office solution? The following factors were, I believe, decisive in reaching a conclusion that may well be regarded as a milestone in the development of the functions of the Presidency in the economic and fiscal field:

I. A recognition of the requirements of the presidential system, as distinct from the cabinet system of government of, for example, Great Britain. The presidential system requires an adequate staff in the Executive Office to assist the President in the performance of the complex duties of present-day government.

פ Secretary Morgenthau submitted a specific proposal for a broad reorganization to the President and, shortly before he left office, to Congress. 
2. A recognition that the budget function is not one among other functions of government, but is the tool which can help in determining the resources to be allocated to the various activities of government. It is a device for coordinating and implementing the program of the Government.

3. From the experience of the depression emerged the conviction that over-all budget and fiscal policy was, along with monetary policy, the most effective instrument serving the objective of full employment and economic stabilization. This, again, was a policy that sometimes involved the conflicting interests and responsibilities of several departments, such as the Departments of Agriculture, Commerce, Labor, Treasury, and others. Therefore, it was a function that would best be performed under the President's direct responsibility.

4. A final argument cannot be found in explicit statements of the President's Committee or in the congressional debate, but there was, I believe, the following very important consideration. Each cabinet member and each department has, by necessity, a special interest in the groups that are his special responsibility. The Secretary of Agriculture has to look after the farm interests and is particularly exposed to pressure from farm groups. In a similar way, each department has its own particular "clientele." The President is supposed to represent the interests of all the people, the general welfare. Can he do it simply by listening to advisers, each of whom approaches the problem with the interests in mind of his particular group? Cabinet members are no longer merely general advisers of the President, but have become largely administrators of their particular departments and, to some extent, trustees for one particular group of the population. This is an unavoidable and by no means undesirable development in modern democracy. It requires, however, a "countervailing power" within the setup of the Government. One argument in favor of a central staff in the Executive Office concerned with fiscal and economic matters is that it forms such a counterweight to the council of the trustees of partial interests. According to this line of thinking, the staff of the Executive Office is supposed to make effective the President's concern for the general objectives of government-which, for the lack of a better term, we call general welfare. Only the President can decide the weight he wishes to give to the views of farm, business, labor and financial groups, and the manner in which they are blended into a program to promote the public interest. In making this decision, he needs the assistance of staff agencies committed only to the formulation and implementation of programs in the public interest.

Economic and Fiscal Functions of the President During the War

The Executive Office began to function in 1939-at a time when the promotion of economic recovery was the main concern of the President. In the over-all direction of this task, he relied primarily on the staff work of the National Resources Planning Board and the Budget Bureau. With the beginning of the defense program in I940, the liquidation of emergency activities (e.g., the Works Progress Ad- 
ministration and the National Youth Administration) had to be synchronized with the increase in defense production. I believe that the New Deal emergency activities could not have been liquidated so promptly had there not been a budget agency working under the direct authority of the President.

During the war, priorities in the use of resources were established primarily through devices of physical control rather than through the use of appropriations. This shifted a major part of the responsibility to the War Production Board and other agencies administering wartime controls. The Executive Office, through the Budget Bureau's budget and management functions, kept in constant touch with the functioning of these control agencies and, indirectly, had a considerable impact on their policies. In addition, some of the supervisory control agencies (e.g., the Office of War Mobilization and Reconversion) were located in the Executive Office which facilitated over-all coordination.

In the fiscal and economic field, price stabilization became a major concern of the President. This was a problem involving tax policy and debt management, as well as price and wage controls. After I94I, the President had the Budget Bureau working on these problems and reporting periodically to him. When prices threatened to get out of hand, the President instructed the Budget Director in March I942 to bring together the heads of departments and agencies involved and present a plan to him for action. President Roosevelt's seven-point stabilization program of April 1942 was the result. The Secretary of the Treasury did not take part in the formulation of this program. ${ }^{3}$

Early in the war, the National Resources Planning Board began preparatory work on postwar economic problems. Towards the end, when victory seemed to be only a matter of time, various agencies of government, both in the legislative and executive branches, together with private organizations, devoted an intensive effort to postwar problems. There was concern that the same factors that made for the depression of the thirties might reappear. In I944, the President instructed the Budget Director and the Chairman of the Board of Governors of the Federal Reserve System to prepare a report for him on postwar economic stabilization policies. The report utilized the work of various government and private agencies. The President used the report as background material for various statements on postwar policies (e.g., in the State of the Union Message of January 1945). It was clear that the pursuit of a full employment and stabilization policy after the war would become a major concern of the President. ${ }^{4}$

\section{The Employment Act of 1946-The Role of the President}

This is not the place to recount the variety of proposals from within and without the Government which finally resulted in the Employment Act of 1946.5 In the

${ }^{3}$ Bureau of the Budget, The United States at War 25 I (1946).

"See Nourse, Defining Our Employment Goal Under the 1946 Act, 38 Rev. EcoN. \& STATIstics 193, 199 (1956).

50 Stat. 23, 15 U. S. C. $\$$ 1022-24 (1946). See Stephen Balley, Congress Makes a Law (1950). 
development of the economic and fiscal functions of the Government in general, and of the President in particular, this act is, next to the Budget and Accounting Act of I92I, the most important step ever taken. The act formalized responsibilities that were already recognized as governmental and presidential duties. Again, there was a sharp difference of opinion as to the proper organizational scheme.

There was one group that suggested the establishment of an independent national economic commission which would make periodic reports on the economic outlook and recommendations for appropriate economic and fiscal policies. These reports would be submitted simultaneously to the President and Congress. The commission was conceived as an independent agency, functioning as a kind of "Supreme Court of Economics," even though its decisions were meant to be advisory only. This view was incorporated in a bill of the Committee on Expenditures in the Executive Departments under the chairmanship of Congressman Menasco.

Another group suggested that making recommendations to Congress on economic and fiscal policy was a duty of the President. The President should be free to set up in the Executive Office (possibly in a reorganized Bureau of the Budget) the staff needed to collect economic analyses from various government and private sources and to coordinate policy recommendations of various agencies and to assist the President in general in this function. This view was reflected in the original Murray bill in the Senate and the Patman bill in the House.

The final result was the Employment Act of 1946, which set up a Council of Economic Advisers in the Executive Office of the President. Let us again see what the issue was with respect to the economic and fiscal functions of the President. Had there been established a national economic commission, the President would not have needed to accept its advice, but it would have been difficult for him, without proper staff, to question an "authoritative" advice made known to Congress at the same time it should be submitted to him. This proposal seemed to imply that it is always possible to give an economic appraisal and to suggest economic policy independent of the Government's program as a whole.

The original proposal in the Murray-Patman bills followed the logic of development under the Budget and Accounting Act of I92I and the Reorganization Act of 1939, making the President directly and fully responsible for economic and fiscal recommendations. A President should not be able to blame an independent commission if he fails in his economic and fiscal policies. He should be fully responsible for selecting advisers in whom he has confidence and not be under any pressure to follow advice which is not persuasive to him. This view has prevailed in the final formulation of the law. How has it worked out?

President Truman stated on the occasion of the tenth anniversary of the Employment Act: "There is almost no other piece of domestic legislation enacted while I was President to which I would attach equal significance." Even though matters

\footnotetext{
- Gerhard Colm (Ed.), The Employment Act Past and Future (National Planning Ass'n, Special Report No. 4I, 1956).
} 
of foreign policy demanded the President's primary attention, he took his responsibility for budget and economic policies very seriously. The fight against inflation became one of the crucial issues of government policy in 1948 and in Mr. Truman's campaign of that year for re-election.

The book by Edwin Nourse, the first chairman of the Council of Economic Advisers, on Economics in the Public Service, reports that while President Truman paid much attention to economic issues, he was ". . . not at all attracted by a contemplative analysis of basic issues ...," but relied largely on horseback judgment. President Truman's failure to "ponder" economic issues with Dr. Nourse could be attributed not to a lack of interest in the economic issues on the side of the President, but perhaps to the fact that he did not feel equal to discussing economics with a man whom he respected as a great scholar and authority. He wanted advice and sought it from many sources, both inside and outside the Government. In most cases, his actions were in accord with the advice given him by the Council. ${ }^{8}$ This brings us to an important point. The degree to which the President fulfills his functions in the economic and fiscal field cannot always be measured by the frequency and duration of discussion with his economic advisers, but must be judged by the policies expressed in the Economic Report and their follow-up and implementation. We are dealing here, strictly speaking, not with personal interests of the President, but with the functioning of the Presidency in the economic and fiscal field. While the frequency of personal discussions are no measurement of the Council's influence, it is probably true that frequent discussions have a symbolic importance. The regular meetings of President Eisenhower with Dr. Burns, in the presence of Dr. Hauge, probably have enhanced the prestige and influence of the Council within the official family of the President and with the public at large.

\section{The Council of Economic Advisers in the President's Official Family}

Very important for successful operation is a good understanding between the Council and the members of the White House staff specializing in economics. There is an advantage for the Council to be somewhat removed from the daily routine as well as the daily excitement of the White House. The Council can fulfill its function only if it has time as well as an atmosphere for reflection. The Council members cannot fulfill their major function if they are involved in every matter in the economics field brought to the attention of the White House; they should be able, however, to bring their influence to bear on those issues in which they feel that their analysis should be considered. The Council will find the proper degree of participation in current issues only if there is a smooth working relationship between the Council and the White House staff.

${ }^{7}$ Edwin G. Nourse, Economics in the Public Service 374 (1953).

${ }^{8}$ I recognize that accord between advice and action by the President may not only prove that the President accepted advice, but also that the advisers avoided making recommendations which would be hard for the President to accept. 
The Council should consist of economists of high professional qualifications in "political economy." They should be in a position to advise the President, placing current issues in the broad perspective of economic development. A White House assistant primarily is an emissary, a writer, a spokesman for the President. The members of the Council, on their part, can fulfill their function only if they have full realization of, and respect for, the political requirements of the President. The White House economic assistant can fulfill his function only if he has understanding and respect for the professional judgment of the economist. And yet, basically there is a division of labor between the professional adviser and the administrative assistant in the economic and fiscal field. From my experience, I can say that between the Council and the White House staff there was developed a good working relationship during the first five years of operation.

The White House staff must be particularly active in insuring that the various presidential statements-the State of the Union Message, the Budget Message, the Economic Report-are consistent with each other. The White House staff can also help in the reconciliation of conflicts between the Council and various departments and agencies. With the presidential assistants taking care of routine work (including preparation of material for presidential speeches and statements), the Council can concentrate on the task given to it under the Employment Act. As an outsider, I have the impression that a very close and smooth working relationship also exists under the present Council and the White House staff concerned with economic affairs. ${ }^{9}$

When the Council of Economic Advisers was set up, Harold D. Smith, who had been Budget Director while the legislation was under consideration, believed that difficulties in the relationship between the Budget Bureau and the Council were likely to appear and that the arrangement provided under the Employment Act would not last very long. Actually, no serious frictions have arisen, or, in any event, none has come to public attention. The Budget Bureau has virtually liquidated its fiscal division, which formerly did much of the work in the field of economic policy coordination and formulation. It is my impression that at present a fairly close working relation exists between the Director of the Budget and the Chairman of the Council but that a real procedure for relating economic programming and budgeting to each other has not yet been worked out.10

${ }^{0}$ The President's Assistant in charge of coordination of public works (Public Works Planning Unit) is located in the White House. This group was set up originally under the Council of Economic Advisers, and previously similar functions were fulfilled by a special unit in the Budget Bureau. The Hoover Commission Task Force (see Report on Real Property Management 18 (r955)) recommended the establishment of such an agency in the Executive Office. The writer assumes that there were considerations of expediency which resulted in the establishment of the Unit in the White House. Obviously this function requires closest cooperation with the Council and the Budget Bureau.

${ }_{10}$ The fact that Budget Bureau and Council are agencies in the Executive Office facilitates relationship, in part because both are located in the same building and because both agencies directly serve the President. Otherwise, the Executive Office of the President has been largely a mere box in an organization chart rather than an internally coordinated unit. What coordination has taken place within the Executive Office is due mainly to good relationships among the heads of the various agencies and particularly to good informal staff relationships. 
It is much more difficult to characterize in a few sentences the relationship between the Council and the cabinet officers. Cabinet officers quite naturally view with misgiving the development of what may appear to them as a staff layer between the President and themselves. The Bureau of the Budget has existed in the present form for more than fifteen years, and cabinet members have more or less accepted the fact that the Budget Director speaks usually with the authority of the President and that a personal recourse to the President in matters of appropriation has rarely changed a determination which the Budget Director had made with the approval of the President. Still not quite straightened out, however, is the relationship between the estimates on the revenue side and on the expenditure side of the budget, which are the responsibilities of the Treasury and Budget Bureau, respectively. With respect to the fiscal year I957 budget, some discrepancies between the assumptions made for the revenue estimates and those for the expenditure estimates were pointed out by the author at recent hearings. ${ }^{11}$

Shortly after the establishment of the Council, a procedure was developed which was designed to give the Council a proper place in the process of economic program development. The President sent a letter to all heads of departments and agencies in the fall of each year asking them to submit their legislative proposals for the next year and indicating that the Council would take up their proposals, as far as they were related to economic policy. These proposals were then usually discussed with officials of the various departments. Task forces were formed for the discussion of programs in which various agencies took an interest (e.g., public works, small business problems, tax policy). In 1948, the President asked Dr. Nourse to set up a cabinet committee under his chairmanship for the consideration of an anti-inflation program. ${ }^{12}$ Mr. Keyserling, after he became Chairman, was asked by the President to participate in certain phases of the work of the National Security Council. Similar assignments have repeatedly been given to the present Chairman of the Council.13 Under the present administration, a new organization was established-the Advisory Board on Economic Growth and Stability-which is a committee of a selected number of sub-cabinet officers. Reports about the workings of this organization are most encouraging.

Thus, progress has been made towards establishing a clearer working relationship between the Council and the various departments and agencies. Some department heads have recognized that their recommendations found more careful consideration when discussed with the Council or in the Advisory Board before being submitted to the President. In the end, a successful relationship can be established only when the heads of the departments and agencies recognize that the Executive

${ }^{11}$ Sce Hearings before the Joint Committee on January 1956 Economic Report of the President, 84 th Cong., $2 \mathrm{~d}$ Sess. I2r ff. (I956). I would like to mention for the readers interested in this problem that a specific method for making uniform assumptions was proposed in this testimony. Sce particularly, id. at $135,148$.

${ }^{12}$ Nourse, op. cit. supra note 7 , at $228 \mathrm{ff}$.

${ }^{13}$ Of interest are the cabinet discussions during the recession of $1953-54$, in which Dr. Burns actively participated, as reported by Robert J. Donovan, The Inside Story 209 ff. (1956). 
Office forms not only an additional layer in the bureaucratic hierarchy, but also affords a channel through which adoption of meritorious proposals may be expedited.

There is a very important function for the Council to fulfill with respect to the coordination of programming activities by the various departments and agencies. The formulation particularly of longer range plans for agriculture, water development, energy development, even social security, and most other programs which extend into the future, must be related to the desired and expected growth of the economy (in the same fashion in which business investment programs are related to general and specific economic bench marks). Orderly procedure requires that consistent economic projections be used as assumptions for the programming by the various departments and agencies. No agency is in a better position than the Council to assist the various agencies in the development of consistent projections. In the early postwar years, the Fiscal Division of the Budget Bureau experimented with work along these lines with various agencies (e.g., the Department of Interior). Similar work was later done informally by the Council staff but, to my knowledge, has never been formalized into a recognized procedure. Recently, Dr. Burns informed the Joint Economic Committee that the Council has been using economic projections in the process of working out Government programs in collaboration with various agencies. ${ }^{14}$ In several fields, the function of longer-range program development must parallel the somewhat shorter-range budget development. In this respect, the Council and Budget Bureau must work hand in hand. ${ }^{15}$ The development of an appropriate procedure for this double purpose is still a task for the future.

A special situation exists with respect to the relationship between the Executive Office and the Board of Governors of the Federal Reserve System. Until the onset of the Great Depression, the monetary authority was looked upon as the main weapon for mitigating economic fluctations. It was generally believed that it could fulfill this function best if it were as independent as possible from Government policy making. This belief was probably influenced by the experience that governments in emergency situations of the past had created money by currency debasement. Therefore, it appeared safer to have the currency administered by an independent agency. However, when in a real national emergency more money was needed than could be raised by taxation or nonbanking loans, the central banks always cooperated with the Government irrespective of their form of organization.

The Federal Reserve System is not independent of the Government. It is created by legislation and reports regularly to the Congress. The decisions of the

${ }^{14}$ Dr. Burns, however, did not give the Joint Committee details about this procedure or about the projections actually used. See Hearings before the Joint Economic Committee on the Jantary 1955 Economic Report of the President, 84th Cong., Ist Scss. 43 (1955).

${ }^{16}$ For a proposal of inclusion in the Economic Report and Budget Message corresponding economic projections and a budget outlook covering several years, see Gerhard Colm, The Federal Budget and the National Economy (National Planning Ass'n Planning Pamphlet No. 90 1955). 
Board of Governors are not, however, subject to direction by the President. Decisions are made by vote of the Governors. The Governors have before them ample information on economic conditions and are aware of the policies of the President and the executive agencies in the economic and financial field. But, in the appraisal of these facts, each Governor votes as his conscience guides him. This independence in the decision of monetary policies might appear to be in conflict with the philosophy of the Employment Act, which states that all the policies of the federal government should be coordinated for accomplishing the objectives of the act. The Chairman of the Board has repeatedly stated that, in the opinion of the Board, the Employment Act does apply to the policies of the Federal Reserve System. ${ }^{16}$ This means that the policies of the Federal Reserve Board should be so directed as to contribute to the accomplishments of the objectives of the Employment Act, unless these objectives are in conflict with other national objectives and obligations. This also means that the President and the Joint Economic Committee, in their respective reports, are bound to include analyses of the economic effects of, and recommendations for, Federal Reserve's policies. In this respect, there has been no difference of opinion, as far as I know. The Board has always cooperated with both agencies in the preparation of these reports. However, the Board has never conceded that the President could direct the Board either to take or not to take any action contrary to the Board's own best judgment. If the Board can act independently of the executive branch, instances may happen in which actions of the Board are not in accord with the policies or opinions of the Executive Office. ${ }^{17}$

A most critical situation developed early in $195 \mathrm{I}$ when President Truman attempted to keep the Federal Reserve policy in line with policies of the Secretary of the Treasury. When the Board demurred, consideration was given to resorting to wartime powers which would have given the Treasury the possibility of full control over the credit policy in an emergency. Actually, the President asked the Secretary of the Treasury, the Chairman of the Federal Reserve Board, the Director of Defense Mobilization, and the Chairman of the Council of Economic Advisers to propose a credit policy which would help in curbing inflation and, at the same time, maintain stability in the federal security markets. When work on a joint report was nearing completion, the Treasury and the Federal Reserve Board announced their "accord" of March 4, I95I. Some observers believed that this accord was

\footnotetext{
${ }^{16}$ Chairman William McC. Martin stated, for instance, before a subcommittee of the Joint Economic Committee on March II, I952: "I am accepting the Employment Act of 1946 as national policy and being applicable to the Federal Reserve System." See Hearings before the Subcommittee on General Credit Control and Debt Management of the Joint Economic Committec on Monetary Policy and the Management of the Public Debt, 82d Cong., 2d Sess. 81 (1952).

17 The latest instance was the increase in the discount rate of certain Federal banks in April 1956. See Hearings bifore the Stebcommittee on Economic Stabilization of the Joint Economic Committee on Conflicting Official Vietus on Monetary Policy, 84th Cong., 2d Sess. (1956). In this connection, sec also the President's statement at his press conference on April 25, 1956: "I really personally belicve it would be a mistake to make [the Federal Reserve Board] definitely and directly responsible to the political head of the State." N. Y. Times, April 26, 1956, p. 16, col. 6.
} 
expedited by the desire of the two agencies to resolve the problem without a reconciliation brought about with the help of the Executive Office of the President. ${ }^{18}$

The independence of the Federal Reserve System has advantages, and the disadvantages may not be serious as long as the members of the Board clearly recognize that the System is committed by the Employment Act to cooperate in the pursuit of the objectives of the act. It is equally important for the executive agencies and the Board to recognize that the Federal Reserve and Treasury policies of debt management have to dovetail with each other and with the President's general economic and fiscal policy. With the clear recognition of these interrelationships the legal form of organization becomes less important. Nevertheless, here lies a problem which at some future time may become acute again. ${ }^{19}$

\section{Council Relationship to Economic Groups and Public}

The Employment Act requires that economic policies under the act shall be determined in consultation and cooperation with private groups of industry, agriculture, employees, consumers, and state and local governments. The first Council, following the suggestion of the act, established several advisory committees and held periodic meetings with each group-usually four times a year.

The present Council believes that it has lived up to the requirements of the act by informal consultation with various interested groups. However, a feeling is expressed by representatives of these groups that the consultation has not been adequate. $^{20}$ The Council does have periodic consultation with academic economists.

\section{Council Relationship to Congress}

No problem has plagued the Council more than the difficulty in establishing a workable relationship with Congress, especially the Joint Economic Committee. Dr. Nourse, ${ }^{21}$ Dr. Burns, ${ }^{22}$ and Mr. Keyserling ${ }^{23}$ have each expressed a different view. Dr. Nourse found testifying before a congressional committee inconsistent with the role of a confidential presidential adviser. Dr. Burns felt that Council members "should respond affirmatively to an invitation to testify before the Joint Committee." "It is equally clear to me," he continued in his letter, "that -except in the case of technical discussions such as those of the Subcommittee on Economic Statistics-the testimony should be given at an executive session and

${ }^{18}$ See Nourse, op. cit. supra note 7 , at 388 .

${ }^{10}$ Neil H. Jacoby, former member of President Eisenhower's Council of Economic Advisers, discusses in his book, Can Prosperity Be Sustained? ( 1956 ), the need to coordinate tax and expenditure policies on the one hand, and monetary policy on the other, and states (at p. 94) that "the President's Council of Economic Advisers has the job of bringing about the necessary coordination."

${ }^{20}$ See ColM, op. cit. supra note 6 , at 80,185 .

22 For Dr. Nourse's view, see his book, op. cit. sttpra note 7 .

32 For Dr. Burns' view, see various statements he made to the Joint Economic Committee, e.g., Hearings, supra note 14 , at $4 \mathrm{ff}$., and particularly his letter of Feb. 3, 1956, to the Chairman of the Joint Economic Committee and the answer by the Chairman of Feb. 27, 1956. Id. at 688, 690.

${ }^{23}$ For Mr. Keyserling's views, see his statement in Hearings, supra note $\mathrm{r} 6$, at $286 \mathrm{ff}$. See also his article, The Council of Economic Advisers' Tasks in the Next Decade, in Cous, op. cit. supra note 6, at $66 \mathrm{ff}$. 
without a transcript."24 I believe that both Dr. Nourse and Dr. Burns felt that questions asked by Committee members about the advice given could drive a wedge between the President and the Council and interfere with the confidential relationship between the President and his advisers. Mr. Keyserling's view was that the privilege of denying testimony applies only to the personal assistants of the President, that is, the White House staff. Heads and staff members of the Budget Bureau and other agencies in the Executive Office are testifying frequently, and there seems to be no convincing reason for the Council to have a different status in this respect. It is also said that Congress can rightly expect to obtain views on the economic outlook on which the economic policy conclusions are based. ${ }^{25}$ The present author sees more validity in the latter view. He believes in the light of the experience of these ten years that:

I. Full cooperation between the Council of Economic Advisers and the Joint Economic Committee is essential for a successful operation under the Employment Act.

2. The Joint Economic Committee has a right to hear on the record the views of the Council on the economic prospects and the effects of various government policies as background for a consideration of the President's recommendations presented in the Report.

3. The Council members should (and are entitled to) refuse to answer questions which probe into confidential advice given to the President, unless the President has consented that such information be given either on or off the record.

4. Matters of serious conflict of opinion in the preparation of the Economic Report usually affect not only the President and his Council, but also officers of other departments and agencies. Therefore, Committee members can ask these agencies about possible conflict in the preparation of the Report. All officers in the Executive branch will avoid discussing the manner in which the President determines policy unless they are authorized to do so.

5. Because many pieces of legislation have an economic aspect, the Council would be called upon to testify so often that their regular work could suffer. Therefore, it would be a desirable rule that the Council should testify only before the Joint Economic Committee (besides the Appropriation Committee and besides hearings at the occasion of confirmation). If another committee has pending important economic legislation, it should ask the Joint Economic Committee to conduct the hearings with members of the legislative committee permitted to be present and to participate in the interrogation.

\section{CoNCLUSION}

We have had an experience of almost twenty years with three different Presidents since the Executive Office was established. This period covered the end of

\footnotetext{
${ }^{24}$ See his letter of Feb. 3, I956, in Hearings, supra note 14, at 688.

${ }^{20}$ For the congressional view on this controversy, see the letter by Senator Paul Douglas, the Chairman of the Joint Committee, Hearings, supra note 14 , at 690 .
} 
a prolonged depression, the Second World War, the Korean War, and the cold war, periods of demobilization and rearmament, recessions and booms. Each of these periods presented different problems in the fiscal and economic field; each of the Presidents had different work methods; and Congress established and rescinded various agencies in the Executive Office.

The experience seems to suggest that under all these conditions, an effective organization in the Executive Office was essential to enable the President to discharge his functions. The philosophy of the Reorganization Act of 1939 has stood the severe test of these times. Great progress has been made in establishing good working relations between the economic and budget agencies within the Executive Office on the one hand, the White House staff, departments, and agencies on the other. However, the relationships with the Treasury and the Federal Reserve Board are not yet finally straightened out. Also, the development of a unified procedure for longer range program development, parallel to the procedure for budget development, is still at the beginning. In the relationships of agencies in the Executive Office to the Congress and the public, there are still a number of unsettled questions. Nevertheless, there is no longer a real question either in Congress or in the public mind about the President's basic responsibility for the conduct of fiscal and economic policy and about the need to provide adequate staff services for these functions in the Executive Office. 